\title{
Interactions between SARS-CoV-2 N-protein and $\alpha$-synuclein accelerate amyloid formation
}

Authors: Slav A. Semerdzhiev*, Mohammad A. A. Fakhree*, Ine Segers-Nolten, Christian Blum, and Mireille M. A. E. Claessens

*These two authors contributed equally to this work

Affiliation: Nanobiophysics, MESA+ Institute for Nanotechnology, Faculty of Science and Technology, University of Twente, P.O. Box 217, 7500 AE Enschede, The Netherlands

Corresponding authors: $\underline{m . m . a . e . c l a e s s e n s @ u t w e n t e . n l, ~ c . b l u m @ u t w e n t e . n l ~}$ 


\begin{abstract}
First cases that point at a correlation between SARS-CoV-2 infections and the development of Parkinson's disease have been reported. Currently it is unclear if there also is a direct causal link between these diseases. To obtain first insights into a possible molecular relation between viral infections and the aggregation of $\alpha$-synuclein protein into amyloid fibrils characteristic for Parkinson's disease, we investigated the effect of the presence of SARS-CoV-2 proteins on $\alpha$-synuclein aggregation. We show, in test tube experiments, that SARS-CoV-2 S-protein has no effect on $\alpha$-synuclein aggregation while SARS-CoV-2 N-protein considerably speeds up the aggregation process. We observe the formation of multi-protein complexes, and eventually amyloid fibrils. Microinjection of N-protein in SHSY-5Y cells disturbed the $\alpha$-synuclein proteostasis and increased cell death. Our results point toward direct interactions between the N-protein of SARS-CoV- 2 and $\alpha$-synuclein as molecular basis for the observed coincidence between SARS-CoV-2 infections and Parkinsonism.
\end{abstract}

\title{
Introduction
}

Symptoms of SARS-CoV-2 infections that cause the current Covid-19 pandemic are not limited to the respiratory tract. The virus also affects other organs and tissues. SARS-CoV-2 has been found in neurons in different brain regions. ${ }^{1,2}$ For many of the patients infected with SARS-CoV-2, acute and subacute neurological complications have been reported. ${ }^{3-5}$ One of these complications, the loss of smell, is a common premotor symptom in Parkinson's disease (PD). This symptom and the recent reports of cases of Parkinson's disease in relatively young patients after a SARS-CoV-2 infection suggests that there may be a link between SARS-CoV2- infections and the development of PD. ${ }^{6}$

The link between viral infections and neurodegeneration is established for some viruses. ${ }^{7-10}$ The most well-known example is the 1918 influenza pandemic (Spanish flu) which coincided with an increase of encephalitis lethargica, followed by numerous cases of post-encephalitic Parkinsonism. ${ }^{11,12}$ In more recent times, multiple indications of a relation between PD and viral infections have been reported. ${ }^{10}$,

${ }^{13}$ Whether viral infections indirectly cause neurodegeneration via the immune system ${ }^{14}$ or if the effect is direct is unclear. Neurodegenerative diseases such as Alzheimer's Disease (AD) and PD are protein aggregation diseases in which specific proteins, tau and $A \beta$ peptide in $A D$ and $\alpha$-synuclein ( $\alpha S$ ) in PD, assemble into amyloid aggregates. Once started, the aggregation process spreads from cell to cell and the formed aggregates and deposits hamper brain function. ${ }^{15-17}$ In a direct mechanism the virus itself triggers the protein aggregation process. The virus would thus be responsible for the onset of the pathological protein aggregation process. Indeed, such a direct relation has been found for $A \beta$ peptide aggregation (AD) in model cell lines and animals infected with herpes simplex and respiratory syncytial virus. $^{18}$

In light of the potential relation between SARS-CoV-2 infections and the development of Parkinson's disease we investigate the direct effect of SARS-CoV-2 proteins on $\alpha \mathrm{S}$ aggregation and $\alpha \mathrm{S}$ proteostasis in model systems. We show, in test tube experiments, that SARS-Cov-2 S-protein has no effect on $\alpha \mathrm{S}$ aggregation while SARS-CoV-2 N-protein considerably speeds up the aggregation process. N-protein and $\alpha \mathrm{S}$ directly interact and this interaction results in the formation of complexes that contain multiple proteins, and eventually amyloid fibrils. Microinjection of N-protein in SHSY-5Y cells disturbed the $\alpha \mathrm{S}$ proteostasis and increased cell death. Our results suggest that the observed link between SARS-CoV-2 infection and Parkinson's disease might originate from a molecular interaction between virus proteins and $\alpha$.

\section{Results}

The nucleocapsid protein ( $\mathrm{N}$-protein) and the spike protein (S-protein) are the most abundant, (partly) soluble structural SARS-CoV-2 proteins with copy numbers of 1000 and $~ 300$ monomers per virus particle respectively. ${ }^{19}$ The net positively charged $\mathrm{N}$-protein packs the negatively charged viral genome 
into a higher order structures. ${ }^{20}$ The $\mathrm{N}$-protein been assigned additional functions during viral infection. ${ }^{21}$ The S-protein is anchored to the membrane where it is exposed on the virus surface and plays a role in receptor recognition, docking and virus entry. ${ }^{22,}{ }^{23}$ The S-protein is the main target in vaccination strategies since it induces the immune response of the infected host. The $\mathrm{N}$-protein is also considered as a target for vaccine development because in the SARS family of viruses the N-protein gene is more conserved and stable than the S-protein gene. ${ }^{24,25}$

Considering their abundance in infected cells we assess if interactions between $\alpha \mathrm{S}$ and $\mathrm{N}$-protein or Sprotein affect the aggregation of $\alpha \mathrm{S}$ into amyloid fibrils in in vitro experiments. In these experiments we followed the aggregation of $\alpha \mathrm{S}$ in the presence and absence of $\mathrm{N}$-protein and S-protein using Thioflavin T (ThT) fluorescence assays. The fluorescence of the dye ThT increases upon binding to amyloid fibrils. ThT fluorescence can therefore be used as a direct readout for fibril formation. A key parameter in such assays is the time to the first (visible) onset of aggregation or aggregation lag time. This time reflects how fast aggregation prone nuclei appear and amyloid fibrils are formed. It thus quantifies the impact of external triggers, like additional proteins, on the aggregation of $\alpha \mathrm{S}$. In the absence of additional proteins, the onset of aggregation of $\alpha \mathrm{S}$ is observed at time scales $>240$ hours (Fig. 1a). We observe no change in the outcome of the aggregation assay in the presence of S-protein (Fig. 1a). In the presence of $\mathrm{N}$-protein we see a strong decrease in the time to the onset of aggregation which reduces to $<24$ hours (Fig. 1b). On long time scales a transition to a second plateau is observed in the presence of $\mathrm{N}$-protein as discussed later in the text.
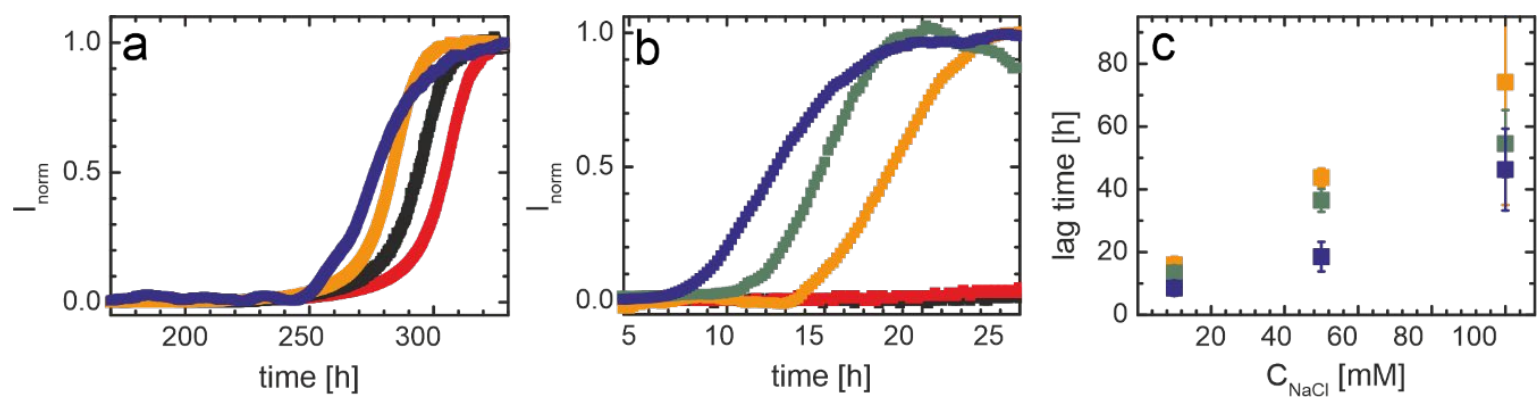

Figure 1 Aggregation of $\alpha \mathrm{S}$ in the absence and presence of SARS-CoV-2 proteins. a) Aggregation assay of $\alpha \mathrm{S}$ in the absence (black) and presence (color) of S-protein. The aggregation process is followed by recording the fluorescence of the amyloid binding dye ThT. The assay was performed at a $\mathrm{NaCl}$ concentration of $10 \mathrm{mM}$ with $50 \mu \mathrm{M} \alpha \mathrm{S}$ and $0.1 \mu \mathrm{M}$ (red), $0.5 \mu \mathrm{M}$ (orange) and $1 \mu \mathrm{M}$ (blue) S-protein. The ThT fluorescence intensity (I) is normalized to the plateau value. b) ThT based aggregation assay of $\alpha \mathrm{S}$ in the presence of $\mathrm{N}$-protein. The assay was performed at a salt concentration of $10 \mathrm{mM} \mathrm{NaCl}$ with $50 \mu \mathrm{M} \alpha \mathrm{S}$ and $0 \mu \mathrm{M}$ (black) $0.1 \mu \mathrm{M}$ (red), $0.5 \mu \mathrm{M}$ (orange), $0.8 \mu \mathrm{M}$ (green) and $1 \mu \mathrm{M}$ (blue) $\mathrm{N}$-protein. The ThT intensity (I) is normalized to the initial plateau value. c) Influence of the salt concentration on aggregation lag time for $\mathrm{N}$-protein concentrations of $0.5 \mu \mathrm{M}$ (orange), $0.8 \mu \mathrm{M}$ (green) and $1 \mu \mathrm{M}$ (blue) at an $\alpha \mathrm{S}$ concentration of $50 \mu \mathrm{M}$. The points represent the mean of 3 independent measurements and error bars show the standard deviation.

We exclude that the increase in ThT fluorescence is the result of N-protein aggregation; at identical concentrations, incubation of $\mathrm{N}$-protein alone does not increase the ThT fluorescence intensity (See SI Figure S1). To quantify the change in the onset of $\alpha \mathrm{S}$ aggregation we determine the aggregation lag time. With increasing $\mathrm{N}$-protein concentration the aS aggregation lag time decreases. This concentration dependent decrease evidences that direct interactions between $\alpha \mathrm{S}$ and N-protein trigger $\alpha \mathrm{S}$ aggregation.

$\mathrm{N}$-protein and $\alpha \mathrm{S}$ are net oppositely charged, near neutral $\mathrm{pH}(7.4)$ the calculated net charge amounts to $+24 \mathrm{e}$ and $-9 \mathrm{e}$ respectively. Electrostatic attraction is therefore likely to play a role in the inter-molecular interactions. Increasing the ionic strength of the solution, and thus screening the electrostatic charge, indeed increases the aggregation lag time (Fig 1c). However, also at higher salt conditions the 
lag time is still considerably shorter in the presence $\mathrm{N}$-protein compared to the control. Moreover, the $\mathrm{N}$-protein concentration dependence of the decrease in the lag time is conserved. Even at the highest salt concentration tested, the time scales at which we observe $\alpha \mathrm{S}$ aggregation do not revert to the > 240 hours observed for $\alpha \mathrm{S}$ alone. We therefore conclude that besides electrostatics other attractive forces contribute to the interaction between $\alpha \mathrm{S}$ and $\mathrm{N}$-protein.
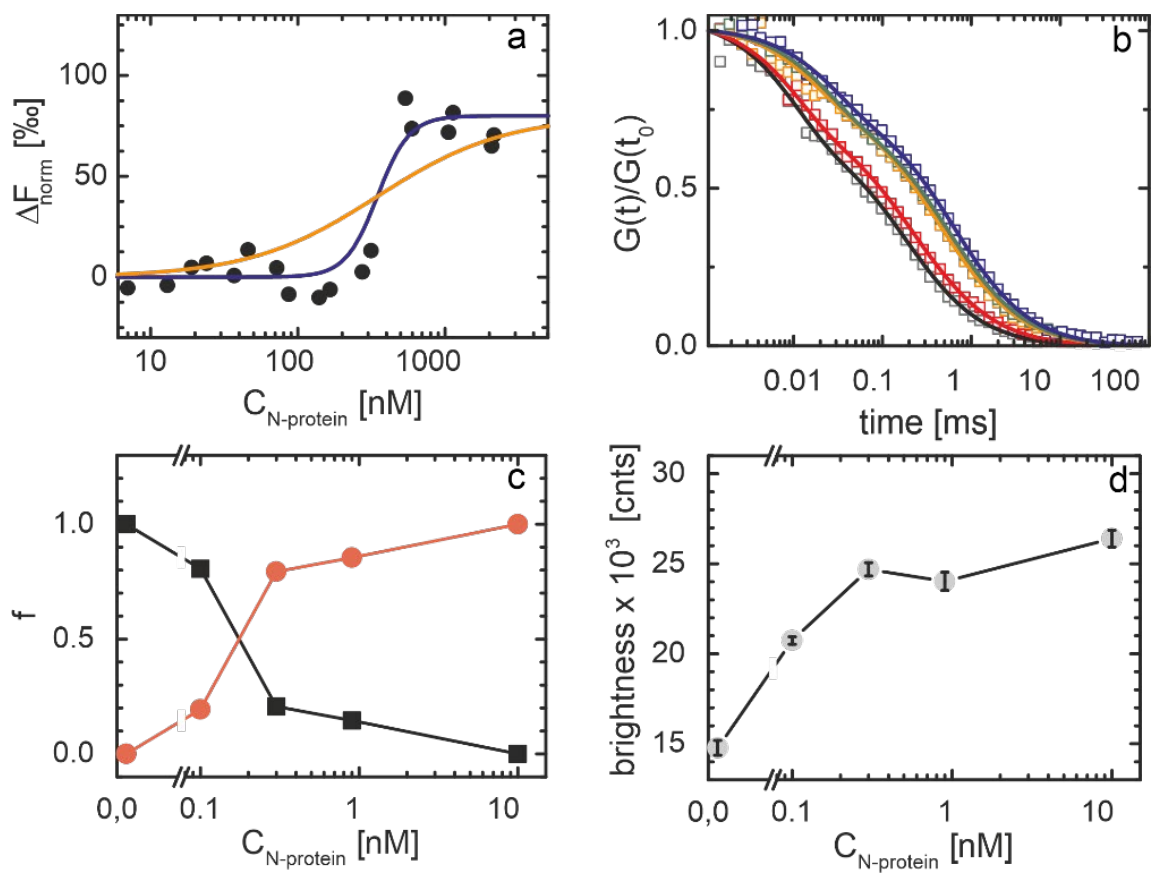

Figure 2 Interaction between $\alpha \mathrm{S}$ and N-protein. a) Binding curve characterizing the interaction between $\alpha \mathrm{S}$ and N-protein obtained from microscale thermophoresis (MST) experiments. MST data points are shown in black. The lines indicate binding with a Hill coefficient of 1 (orange) and 4 (blue) and an $\mathrm{EC}_{50}$ of $0.3 \mu \mathrm{M}$. These curves serve as a guide to the eye. b) FCS autocorrelation curves normalized to $\mathrm{G}\left(\mathrm{t}_{0}\right)$ (where $\mathrm{t}_{0}=0.001 \mathrm{~ms}$ ) (hollow symbols) of fluorescently labelled $\alpha \mathrm{S}$ in the presence of $0 \mu \mathrm{M}$ (black), $0.1 \mu \mathrm{M}$ (red), $0.3 \mu \mathrm{M}$ (orange), $0.9 \mu \mathrm{M}$ (green) and $10 \mu \mathrm{M}$ (blue) N-protein. Not all data points are shown for clarity. Fits to the autocorrelation curves are visible as lines with the corresponding color. In fitting the curves a triplet fraction was considered, and a fast and a slow diffusing component when necessary. c) Fractions ( $f$ ) of the slow (red) and fast (black) diffusing components obtained from the fits to the autocorrelation curves shown in $b$. The errors bars show the standard deviation in the observed brightness. d) Average particle brightness as a function of the N-protein concentration.

To obtain insight into the strength of the interaction between $\alpha \mathrm{S}$ and $\mathrm{N}$-protein we performed a microscale thermophoresis assay. Microscale thermophoresis (MST) relies on changes in the diffusion coefficient of a particle upon binding to a partner. In the experiment one of the partners needs to be fluorescently labelled and labelling the one with the lower molecular weight provides optimal contrast. In our experiments we therefore fluorescently labelled $\alpha \mathrm{S}$. The concentration of fluorescently labelled $\alpha \mathrm{S}$ was kept constant and the MST response was studied as a function of the $\mathrm{N}$-protein concentration. The lower and higher plateau in the MST signal were interpreted as free $\alpha \mathrm{S}$ and $\alpha \mathrm{S}$ bound to N-protein respectively (Figure 2a). We observe a sharp transition from the unbound to bound state of $\alpha \mathrm{S}$ and an $\mathrm{EC}_{50}$ of approximately $0.3 \mu \mathrm{M}$. The steepness of the transition indicates that binding is cooperative.

Fluorescence correlation spectroscopy (FCS) experiments were performed to obtain first insights into the number of $\alpha \mathrm{S}$ molecules in $\alpha \mathrm{S} / \mathrm{N}$-protein complexes. In the FCS experiment $\alpha \mathrm{S}$ was fluorescently labelled. Upon increasing the $\mathrm{N}$-protein concentration we observe a strong shift in the correlation curves to longer times, indicating the formation of slow diffusing complexes (Figure $2 b$ ). For $\alpha \mathrm{S}$ alone, 
the FCS autocorrelation curve can be fitted to a single diffusing species with a diffusion coefficient of approximately $86 \mu \mathrm{m}^{2} / \mathrm{s}$, in agreement with the expected size of the protein and earlier findings. ${ }^{26}$ With increasing $\mathrm{N}$-protein concentration a second slower diffusing species with a diffusion coefficient of approximately $27 \mu \mathrm{m}^{2} / \mathrm{s}$ appears. In figure $2 \mathrm{c}$ we plot the fraction of both the slow and fast diffusing species as a function of the N-protein concentration. In agreement with the MST data, we observe a transition from the unbound to bound state that is cooperative and an $\mathrm{EC}_{50}$ of $\sim 0.2 \mu \mathrm{M}$. Concomitant with the appearance of the $\alpha \mathrm{S} / \mathrm{N}$-protein complex, we observe an increase of the average brightness of the diffusing protein complexes (Figure $2 \mathrm{~d}$ ). In the $\alpha \mathrm{S} / \mathrm{N}$-protein complex the brightness increased by a factor of 1.8 times compared to unbound $\alpha \mathrm{S}$. Considering that of the total $\alpha \mathrm{S}$ concentration of 20 $\mathrm{nM}$, only half was labelled and ignoring the possible fluorescence quenching due to fluorophore-fluorophore interactions that has been observed in other protein systems under certain conditions, this indicates that on average 3 to $4 \alpha \mathrm{S}$ proteins are present in an $\alpha \mathrm{S} / \mathrm{N}$-protein complex. Note that although this indicates that $\mathrm{N}$-proteins accumulate $\alpha \mathrm{S}$, the FCS experiment was performed in excess of $\mathrm{N}$-protein. ${ }^{27}$ The aggregation experiments were performed in excess of $\alpha S$, accumulation of even higher numbers of $\alpha \mathrm{S}$ on $\mathrm{N}$-protein is therefore likely. We conclude that the decrease in $\alpha \mathrm{S}$ aggregation lagtime in the presence of $\mathrm{N}$-protein results from direct interactions between the two protein species and the accumulation of $\alpha \mathrm{S}$ on $\mathrm{N}$-proteins.

The increase in ThT fluorescence intensity during $\alpha \mathrm{S}$ aggregation in the presence of $\mathrm{N}$-protein deviates from the typically observed pattern. Instead of the typical single step nucleation and growth process, we observe two growth steps. At longer time scales a second, higher, plateau in the ThT fluorescence intensity appears (Figure 3a). To verify that in both plateaus the observed ThT fluorescence results from the formation of amyloid fibrils, we performed atomic force microscopy (AFM) experiments. We obtained samples for AFM experiments that cover both the first and the second plateau in ThT fluorescence. AFM images obtained from samples in both plateaus in ThT fluorescence show the presence of helical amyloid fibrils (Figure 3b,c). The AFM images however indicate that the morphology of the fibrils is different in both plateaus. In the first plateau, fibrils of two different morphologies can be discriminated. These fibrils differ in helical periodicity. To determine the periodicity of the helix, a direct Fourier transform (DFT) was performed on the images of fibrils formed in both plateaus. We observe two clear peaks in the DFT analysis at periodicities of approximately $\approx 130 \mathrm{~nm}$ and $\approx 90 \mathrm{~nm}$ (Figure $3 d$ ). The morphology of fibrils in the samples obtained in the second plateau is homogeneous (Figure 3d). DFT analysis shows that these fibrils have a periodicity of $130 \mathrm{~nm}$ (Figure 3d). This periodicity agrees with previous AFM and cryo-electron microscopy studies on the structure of $\alpha \mathrm{S}$ amyloid fibrils in the absence of $\mathrm{N}$-protein. ${ }^{28} \mathrm{~N}$-protein speeds up the formation of $\alpha \mathrm{S}$ fibrils but does not change the morphology of fibrils observed after long time incubation.
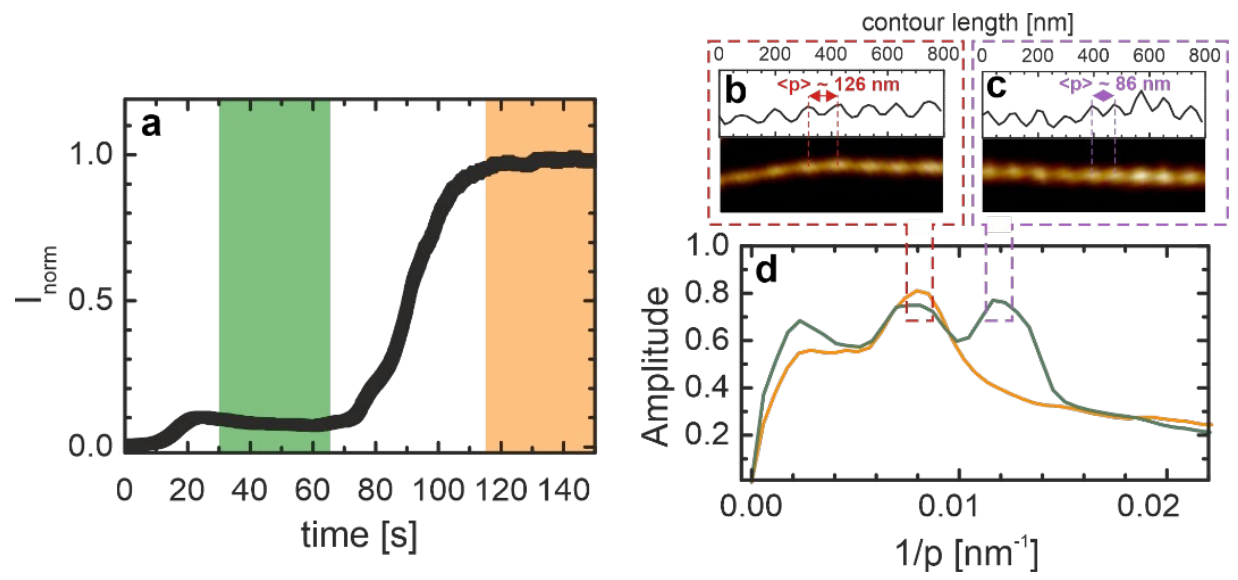

Figure 3 Aggregation of $\alpha \mathrm{S}$ into amyloid fibrils in the presence of N-protein. a) Full ThT aggregation curve of $\alpha \mathrm{S}$ in the presence of $\mathrm{N}$-protein $(1 \mu \mathrm{M} \mathrm{N}$-protein, $50 \mu \mathrm{M} \alpha \mathrm{S}, 50 \mathrm{mM} \mathrm{NaCl})$. The data is normalized to the final plateau in ThT intensity. The colors refer to the color coding in d. b), c) In the AFM images two distinctly different fibril populations, with different morphologies, can be discriminated. The cross-sections along the 
bioRxiv preprint doi: https://doi.org/10.1101/2021.04.12.439549; this version posted April 12, 2021. The copyright holder for this preprint (which was not certified by peer review) is the author/funder. All rights reserved. No reuse allowed without permission.

length of the fibrils (top) show these fibrils differ in helical periodicity. d) Discrete Fourier analysis on fibrils obtained in the first (green) and second (orange) plateau. In first plateau 2 populations with different periodicity $(p)$ of $\approx 90 \mathrm{~nm}$ and $\approx 130 \mathrm{~nm}$ are observed (green line). The peak at low $1 / p$ values is an analysis artifact. In the second plateau, fibrils with a $p=130 \mathrm{~nm}$ dominate the population, in the analysis fibrils with a periodicity $p=90 \mathrm{~nm}$ are no longer visible (orange line). A total of 79 and 72 fibrils were analyze for the first and second plateau respectively.

Above we have shown proof that the direct interaction between $\mathrm{N}$-protein and $\alpha \mathrm{S}$ triggers $\alpha \mathrm{S}$ aggregation into amyloid fibrils in in vitro experiments. Next, we have conducted microinjection experiments to investigate the effect of the presence of $\mathrm{N}$-protein in a cellular context. From literature data we estimate the concentration of $\mathrm{N}$-protein in infected cells to be of the order of $500 \mathrm{nM} .{ }^{19}$ The injected $\mathrm{N}$-protein concentration and injection volume were chosen to approximately result in this concentration in the cells and to mimic concentrations expected in infections (see Materials and Methods).

The intrinsically disordered protein $\alpha \mathrm{S}$ has been suggested to have many functions. In the cell, $\alpha \mathrm{S}$ is found on trafficking vesicles and its main function most likely involves membrane remodeling in membrane trafficking processes. ${ }^{29-36}$ Bound to the membranes of vesicles $\alpha \mathrm{S}$ adopts an $\alpha$-helical conformation that can be discriminated from the unstructured protein (or other conformational states) in Förster resonance energy transfer (FRET) experiments. ${ }^{37,} 38$ These FRET probes used in in vitro experiments have also been applied to identify and localize membrane bound $\alpha \mathrm{S}$ in cells. ${ }^{39} \mathrm{It}$ is thus possible to use FRET to discriminate between conformational subensembles that potentially represent different functions and thereby gain insights into the $\alpha \mathrm{S}$ proteostasis.

SH-SY5Y cells express $\alpha$ S and are a well-established neuronal cell model in PD research. With these cells, two different sets of experiments were performed. In one set, single cells were microinjected with both FRET labelled $\alpha \mathrm{S}$ and $\mathrm{N}$-protein and fixed 5 days after injection. In a second set of experiments the cells were injected with FRET labelled $\alpha \mathrm{S}$ and N-protein and additional unlabelled $\alpha \mathrm{S}$ and fixed 3 days after injection. We expect that the redistribution of $\alpha \mathrm{S}$ from functional to dysfunctional states is a slow process. We hypothesize that by either giving the cells more time or by increasing the $\alpha S$ concentration this redistribution may become visible. In these experiments, the cells injected with only FRET labeled $\alpha \mathrm{S}$ served as a control. After fixation, cells were counterstained with DAPI and imaged using a confocal fluorescence microscope.

Compared to the control where approximately $10 \%$ rounded up/dead cells are observed, we find approximately double the amount of dead cells after microinjection of $\mathrm{N}$-protein. Typical images of the surviving injected cells are presented in Figure 4a. In the control, we see the previously reported distribution of $\alpha \mathrm{S}$ between a high FRET vesicle bound and a low FRET cytosolic $\alpha \mathrm{S}$ population. ${ }^{39}$ Vesicle bound $\alpha \mathrm{S}$ is clearly present in orange (high FRET) fluorescent puncta, while cytosolic $\alpha \mathrm{S}$ is visible as a spread out green (low FRET) background. The overall appearance of the FRET signal from cells that were co-injected with $\mathrm{N}$-protein is very similar, both high FRET fluorescent puncta and low FRET spread out cytosolic signal can be found. However, in the cells that were microinjected with N-protein, we observe less high FRET (orange) signal compared to the control group (Fig. 4a). This indicates that in the presence of $\mathrm{N}$-protein, the $\alpha \mathrm{S}$ proteostasis is disturbed resulting in less vesicle bound $\alpha \mathrm{S}$. 

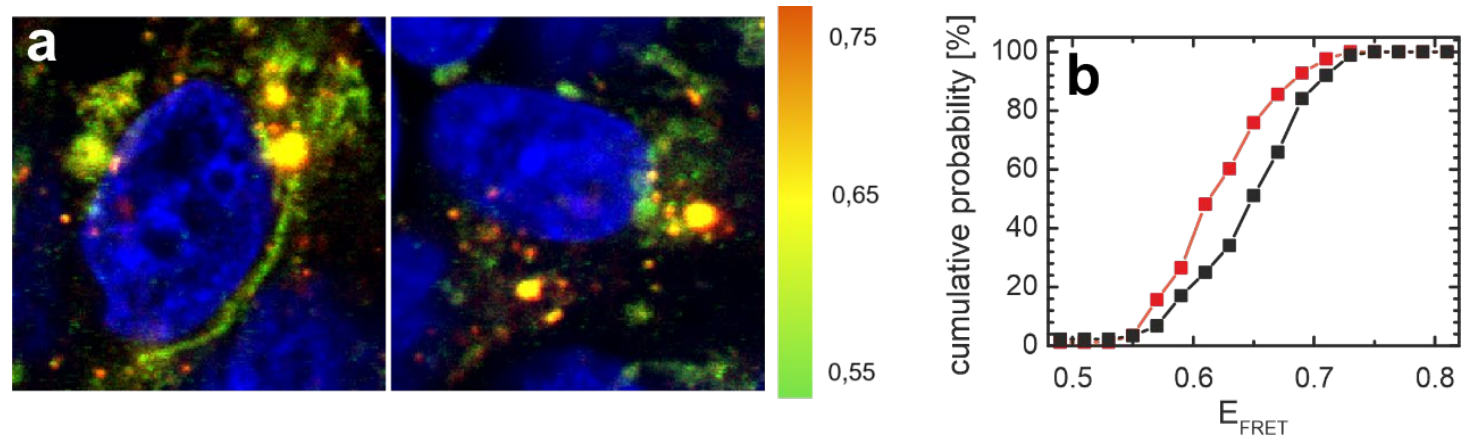

Figure 4. Distribution of $\alpha \mathrm{S}$ in SH-SY5Y cells is affected by N-protein. a) FRET images of cells microinjected with the $\alpha S$ FRET probe. The color coding represents $E_{F R E T}$ (green: low $E_{F R E T}$; yellow: mid $E_{F R E T}$; orange: high $E_{F R E T}$ ). The cell nucleus is counterstained with DAPI and visible in blue. A representative image of cells co-injected with N-protein and the $\alpha$ S FRET probe is shown on the left, the control cells on the right were only injected with the $\alpha S$ FRET-probe. b) Distribution of average FRET efficiencies of $\alpha$ S per image for all cells injected with $\mathrm{N}$-protein (red) and control cells (black). The cumulative histograms contain data from at least 80 images for both the control and the N-protein injected samples. The average FRET efficiency of $\alpha \mathrm{S}$ in cells injected with $\mathrm{N}$-protein is shifted to lower EFRET values.

To substantiate the visual impression that in the presence of $\mathrm{N}$-protein an overall average lower FRET value is observed, we estimated the $\alpha$ S FRET efficiency $\left(E_{\text {FRET }}=\right.$ intensity acceptor/(intensity donor + intensity acceptor)) averaged over all pixels for each image made (Materials and Methods). Subsequently we plotted cumulative histograms for the averaged $\alpha$ S FRET efficiency per image for the $\mathrm{N}$-protein injected cells together with the controls (see SI Figure S2). The histograms obtained for 3 and 5 days after microinjection agree well. For both sets of experiments the distribution of the $\alpha$ S FRET efficiencies for the $\mathrm{N}$-protein injected cells is shifted to lower values compared to the control. For the control samples, the mean aS FRET efficiencies quantitatively agree (see SI Figure S2). The width of the distribution is slightly enhanced for the control data obtained 5 days after microinjection. The good agreement between the data sets justifies accumulation of the data. In figure $4 \mathrm{~b}$ we show the cumulative distribution of FRET efficiencies of $\alpha \mathrm{S}$ in all control cells and all cells injected with N-protein. Compared to the control, the FRET efficiency distribution of $\alpha \mathrm{S}$ in cells injected with N-protein is systematically shifted to lower values. Our data shows that the presence of $\mathrm{N}$-protein results in redistribution of $\alpha \mathrm{S}$ between (dis)functional conformational states. In vitro experiments shows that the observed change in FRET efficiency does not result from a direct interaction between the $\mathrm{N}$ terminus of $\alpha \mathrm{S}$ and $\mathrm{N}$-protein. Even in the presence of excess $\mathrm{N}$-protein where we expect all $\alpha \mathrm{S}$ to be bound, we do not observe a change in FRET efficiency of the FRET labelled $\alpha \mathrm{S}$ compared to the control (see SI Figure S3). The N-protein does apparently not interact with $\alpha \mathrm{S}$ in the FRET labelled N-terminal region or this binding does not induce measurable conformational changes in $\alpha \mathrm{S}$.

\section{Discussion}

The in vitro experiments on recombinantly expressed proteins show that SARS-CoV-2 S-protein does not affect the aggregation of $\alpha \mathrm{S}$ into amyloid fibrils. The SARS-CoV-2 N-protein however, very effectively decreases the time to the onset of $\alpha \mathrm{S}$ aggregation. Additionally, the aggregation process in the presence of $\mathrm{N}$-protein differs from the aggregation process of $\alpha \mathrm{S}$ alone. In the presence of $\mathrm{N}$-protein, aggregation of $\alpha S$ proceeds in two steps, represented by two plateaus in the ThT fluorescence. The analysis of AFM images of fibrils shows that two populations of fibrils with a helical periodicity of approximately $90 \mathrm{~nm}$ and $130 \mathrm{~nm}$ are present during the first plateau phase. Only a single population of fibrils with a helical periodicity of $130 \mathrm{~nm}$ is found in the second plateau. The fibrils with the smaller helical periodicity are no longer observed. Although aggregation of $\alpha \mathrm{S}$ in the presence of $\mathrm{N}$-protein proceeds 
in two steps, first fibril nucleation is fast. The first plateau in the ThT fluorescence is found at a relatively low ThT intensity which indicates that the produced fibril mass is not very high. The fibrils formed in the first phase trigger the formation of or conversion to a second, thermodynamically more stable, fibril polymorph. The higher stability of this polymorph results in an increase of fibril mass and a plateau of higher ThT intensity. Note that the timescales on which the second polymorph appears is still fast compared to amyloid fibril formation in the absence of $\mathrm{N}$-protein.

The MST and FCS data show that there is a direct interaction between N-protein and $\alpha \mathrm{S}$. The binding of the $\alpha \mathrm{S}$ to the net positively charged $\mathrm{N}$-protein appears to be mediated by attractive electrostatic interactions. This indicates that interaction involves the negatively charged C-terminus of $\alpha \mathrm{S}$. The absence of a change in the FRET efficiency of the $\alpha$ SRET probe confirms that the interaction with the Nprotein is likely mediated via the C-terminal region or the aggregation prone central NAC region of $\alpha \mathrm{S}$. In solution, electrostatic repulsion between net negatively charged $\alpha \mathrm{S}$ proteins prevents their aggregation. Charge compensation due to binding to N-protein, not only exposes the aggregation prone NAC region of $\alpha \mathrm{S}$ but also eliminates electrostatic repulsion of other $\alpha \mathrm{S}$ proteins. Our data also shows that the complexes contain multiple $\alpha \mathrm{S}$ proteins. The close proximity of multiple $\alpha \mathrm{S}$ proteins in the complex in an aggregation prone conformation potentially facilitates the formation of a nucleus that triggers further aggregation and thus decreases the time to the onset of aggregation. ${ }^{40}$

Even in the complex environment of the cell we see clear signs that the presence of the N-protein markedly affects $\alpha$ S proteostasis. In the cell, $\alpha$ S exists in at least two different conformational subensembles. The presence of the $\mathrm{N}$-protein results in a change of the FRET efficiency distribution and hence in either a change in the population of the sub-ensembles or in the appearance of a new conformation. In the microinjection experiments on cells, the concentration of $\mathrm{N}$-protein is low compared to the concentration of $\alpha \mathrm{S}$. It is therefore rather remarkable that we can detect a clear shift in the distribution of the $\alpha$ S FRET efficiencies.

The presence of $\mathrm{N}$-protein indirectly affects the FRET efficiency of the $\alpha$ S FRET probe by disturbing $\alpha \mathrm{S}$ proteostasis. The affinity of $\alpha \mathrm{S}$ for $\mathrm{N}$-protein is of the same order of magnitude or higher as the affinity reported for other $\alpha \mathrm{S}$ interactions. ${ }^{41-43}$ Therefore, the N-protein will compete with other $\alpha \mathrm{S}$ binding partners for interactions inside the cell. For reliable cellular performance, protein interaction networks must be robust. Small changes and additional binding partners are therefore not expected to easily disturb interaction networks. We however do see a clear redistribution of $\alpha \mathrm{S}$ over (dis)functional states even at the rather short time scales studied. The observed increase in the fraction of images containing dead cells, further supports the idea of an imbalance in the cells proteostasis after injection with $\mathrm{N}$ protein. We cannot confirm that this imbalance is the result of $\alpha \mathrm{S}$ aggregation and the presence of amyloid fibrils in the cells injected with $\mathrm{N}$-protein although we observe elongated and fibril mesh like structures. Considering that Parkinson's disease typically develops on very long time scales, absence of fibrils in the microinjected cells would not be surprising.

Summarizing, we have identified a SARS-CoV-2 protein that induces the aggregation of $\alpha \mathrm{S}$ in the test tube. In the initial interaction between the SARS-CoV- $2 \mathrm{~N}$-protein and $\alpha \mathrm{S}$, multi-protein complexes are formed. In the presence of $\mathrm{N}$-protein the onset of $\alpha \mathrm{S}$ aggregation into amyloid fibrils is strongly accelerated, indicating that $\mathrm{N}$-protein facilitates the formation of a critical nucleus for aggregation. Fibril formation is not only faster, but also proceeds in an unusual two-step process. In cells, the presence of $\mathrm{N}$-protein changes the distribution of $\alpha \mathrm{S}$ over different conformations that likely represent different functions at already short timescales. Disturbance of $\alpha \mathrm{S}$ proteostasis might be a first step towards nucleation of fibrils. Our results point toward a direct interaction between N-protein of SARS-CoV-2 and $\alpha S$ as molecular basis for the observed relations between virus infections and parkinsonism. The 
observed molecular interactions thus suggest that SARS-CoV-2 infections may have long term implications and that caution is required in considering $\mathrm{N}$-protein as an alternative target in vaccination strategies.

\section{Materials and Methods}

$\alpha S$ Production: Expression of recombinant human $\alpha \mathrm{S}$, the $140 \mathrm{C}$ mutant $\alpha \mathrm{S}(140 \mathrm{C})$ with a single alanine to cysteine substitution at residue 140 and the double cysteine mutant $\alpha \mathrm{S}(9 \mathrm{C} / 69 \mathrm{C})$ was performed in E. coli B121 (DE3) using the pT7-7-based expression system. Details on the purification procedure are described elsewhere. ${ }^{44}$

Preparation of labelled $\alpha S$ : To visualize the microinjected $\alpha S$ in cells, the $\alpha S(9 C / 69 C)$ was labelled with a FRET pair as described before. ${ }^{39}$ In short the cysteines in the $\alpha \mathrm{S}(9 \mathrm{C} / 69 \mathrm{C})$ were reduced with DDT. After removal of DDT, an equimolar concentration of the maleimide derivative of AF488 was added to $0.5 \mathrm{ml}$ of $200 \mu \mathrm{M} \alpha \mathrm{S}(9 \mathrm{C} / 69 \mathrm{C})$ and incubated for 1 hour at room temperature. To remove unreacted dye and DTT a Zeba Spin desalting column (Pierce Biotechnology) was used. The labelled protein was applied to a Thiopropyl Sepharose 6B column (GE Healthcare Life Sciences) to remove double labelled protein. Column bound single-labeled and/or unlabeled $\alpha \mathrm{S}$ was eluted using $10-15 \mathrm{ml}$ of $10 \mathrm{mM}$ Tris$\mathrm{HCl}, \mathrm{pH} 7.4$ buffer, containing $\beta$-mercaptoethanol. Subsequently a $2-3 \mathrm{x}$ molar excess of maleimide functionalized AF568 was added. After incubation for 1 hour at room temperature, free dye was removed using two desalting steps and the solution was filtered through a Microcon YM100 filter (Millipore, Bedford, MA). In the main text the FRET labelled $\alpha \mathrm{S}(9 \mathrm{C} / 69 \mathrm{C})$ protein is referred to as the $\alpha \mathrm{S}$ FRET probe. Single labelled $\alpha S$ was prepared using the $\alpha \mathrm{S} 140 \mathrm{C}$ cysteine mutant which was incubated with 2-3x molar excess of AF488 or AF647 maleimide. The free dye was removed using the protocol mentioned above.

Aggregation assays: $50 \mu \mathrm{M} \alpha \mathrm{S}$ was aggregated in the presence of SARS-CoV-2 N-protein (PKSR030485, Elabscience, US) and S-protein (10549-CV-100, R\&D systems, UK) at concentrations specified in the main text, $20 \mathrm{mM}$ Tris buffer (Sigma-Aldrich, UK), pH = 7.4, $5 \mu \mathrm{M}$ Thioflavin T (ThT, Fluka, Sigma-Aldrich, UK) and different concentrations of $\mathrm{NaCl}$ (Sigma-Aldrich, USA) as mentioned in the main text. The aggregations were performed in a 96-well half area clear flat bottom polystyrene NBS (low bind) microplate (3881, Corning, US) while shaking at 500 RPM and $37^{\circ} \mathrm{C}$. To follow the formation of amyloid fibrils the increase of ThT fluorescence was monitored using a plate reader (Infinite 200 Pro, Tecan Ltd., Switzerland). The ThT dye was excited at $446 \mathrm{~nm}$ and the fluorescence signal was measured at $485 \mathrm{~nm}$ every 10 minutes. Samples were prepared in 3-5 replicates of $50 \mu \mathrm{l}$. The lag time is defined as the time point at which a twofold increase in the fluorescence intensity compared to the initial intensity values (baseline) is observed.

Microscale thermophoresis: The binding between $\alpha \mathrm{S}$ and $\mathrm{N}$-protein was studied using a Monolith NT.115 (NanoTemperTechnologies GmbH, Germany) MST system. The thermophoretic movement was monitored at a constant $20 \mathrm{nM}$ concentration of $\alpha \mathrm{S} 140 \mathrm{C}-\mathrm{AF} 488$, and a dilution series of concentrations of $\mathrm{N}$-protein. Samples were prepared in $20 \mathrm{mM}$ Tris- $\mathrm{HCl}, \mathrm{pH} 7.4,10 \mathrm{mM} \mathrm{NaCl}$ and transferred to capillaries (Standard treated, NanoTemper Technologies $\mathrm{GmbH}$, Germany), measurements were performed at $37{ }^{\circ} \mathrm{C}$ with a constant blue LED power of $20 \%$ and at MST infrared laser powers of $40 \%$ to induce thermophoretic motion. For each capillary the infrared laser was switched on $10 \mathrm{~s}$ after the start of the measurement for a $30 \mathrm{~s}$ period, followed by another $10 \mathrm{~s}$ period with a turned off infrared laser to record the back diffusion. Data were analyzed with the MO.Affinity Analysis software. 
Fluorescence microscopy and fluorescence correlation spectroscopy: Fluorescence images were obtained on a laser scanning confocal microscope (MicroTime 200 with a FlimBee scanner, PicioQuant, Germany). To excite either DAPI or FRET labelled $\alpha$ sequential $405 \mathrm{~nm}$ and $485 \mathrm{~nm}$ laser excitation in combination with a dichroic mirror (ZT405/485rpc-UF3, Chroma, USA) was used. A UPlanSApo, 60x, 1.2 NA objective (Olympus, Japan) was used for imaging. Emission was detected with Single Photon Counting Modules (SPCM-AQRH-15, Excelitas, Canada). DAPI emission was detected via a bandpass filter (F02-447/60-25, Semrock, USA), emission from the FRET pair via a 488 long pass emission filter (LP02-488RU-25, Semrock, USA). The FRET signal was further split by a $585 \mathrm{~nm}$ dichroic beam splitter (T585Ipxr, Chroma, USA) into a green channel (bandpass FF01-520/35-25, Semrock, USA) for detection of the FRET-donor signal and a red channel (bandpass BA590, Olympus, Japan) for detection of the FRET-acceptor signal. Fluorescence intensity images were exported as raw data and used for image analysis and visualization purposes.

The fluorescence correlation spectroscopy (FCS) experiments were performed on the same setup. For the FCS experiments samples were prepared containing $10 \mathrm{nM} \alpha \mathrm{S} 140 \mathrm{C}-\mathrm{AF} 647,10 \mathrm{nM} \alpha \mathrm{S}$ (total of 20 $\mathrm{nM} \alpha \mathrm{S}$ ) and a range of $\mathrm{N}$-protein concentrations in $20 \mathrm{mM}$ Tris buffe, $\mathrm{pH}$ 7.4. To excite AF647 labelled $\alpha \mathrm{S}$, a $640 \mathrm{~nm}$ laser was used. Excitation light was reflected towards the sample and emission was separated from excitation light using a dichroic mirror (ZT488/640rpc-UF3, Chroma, USA). The emission was further filtered spectrally by a $690 \mathrm{~nm}$ bandpass. Before detection the emission was filtered spatially by a $100 \mu \mathrm{m}$ pinhole. Autocorrelation curves were calculated and analyzed using the SymPhoTime 64 software. A diffusion model that includes the triplet state population was used to fit the data. For each experimental condition, 10 measurements with duration of 10 seconds were recorded and analyzed.

Atomic force microscopy: A $10 \mu \mathrm{l}$ volume of 5 times diluted aggregated sample (initial $\alpha$ S concentration $=50 \mu \mathrm{M}$ and $\mathrm{N}$-protein concentration $=0.2-1 \mu \mathrm{M}$ ) was deposited onto freshly cleaved mica (Muscovite mica, V-1quality, EMS, US) and left to rest for $5 \mathrm{~min}$. Then the sample was carefully washed 4 times with $20 \mu$ lof demineralized water (MilliQ) and gently dried under a low flow of nitrogen gas. AFM images were acquired using a BioScope Catalyst (Bruker, US) in soft tapping mode using a silicon probe, NSC36 tip B with a force constant of $1.75 \mathrm{~N} / \mathrm{m}$ (MikroMasch, Bulgaria). Images were captured with a resolution of $512 \times 512(10 \mu \mathrm{m} \times 10 \mu \mathrm{m})$ pixels per image at a scan rate of 0.2 to $0.5 \mathrm{~Hz}$. AFM images were processed with the Scanning Probe Image Processor (SPIP, Image Metrology, Denmark) and the Nanoscope Analysis (Bruker, Us) packages. Fibril morphology was analyzed using a custom fibril analysis Matlab script adapted from the FiberApp package. ${ }^{45}$

Fluorescence spectroscopy: A Varian Eclipse spectrofluorometer was used to record bulk emission spectra of the FRET labelled $\alpha \mathrm{S}(9 \mathrm{C} / 69 \mathrm{C})(500 \mathrm{nM})$ and SARS CoV-2 N-protein $(5 \mu \mathrm{M})$ mixtures in 1xPBS buffer. The samples were pipetted into a $3 \mathrm{~mm}$ quartz cuvette and excited at $488 \mathrm{~nm}$ wavelength, and emission was collected from $500 \mathrm{~nm}$ to $700 \mathrm{~nm}$, with a slit width of $5 \mathrm{~nm}$ both for excitation and emission.

Cell culture, microinjection, and nuclear counterstaining: SH-SY5Y cells (ATCC, USA) were grown in proliferation medium (DMEM-F12 GlutaMAX ${ }^{\mathrm{TM}}+10 \%$ heat inactivated FBS $+1 \%$ non-essential amino acids +10 mM HEPES buffer $+1 \%$ Penicillin/Streptomycin; Gibco ${ }^{\circledR}$, Invitrogen, USA). For microinjection the cells were seeded on glass bottom $\mu$-Dishes with a cell location grid (grid-50, $35 \mathrm{~mm}$, ibidi ${ }^{\circledR}$, Germany). Dishes in which the cell confluency reached $70 \%$ to $90 \%$ were used for microinjection.

The microinjections were performed as described before. ${ }^{39}$ In short, the microinjections were performed using a FemtoJet ${ }^{\circledR}$ (Eppendorf, Germany), equipped with a manual hydraulic 3D micromanipulator (Narishige, Japan). For injection, $\mathrm{UV}-\mathrm{O}_{3}$ cleaned glass micropipettes with an inner diameter of 
approximately $400 \mathrm{~nm}$ (WPI, USA) were used. For microinjection the following concentrations of proteins in PBS were used, $500 \mathrm{nM}$ FRET labeled $\alpha \mathrm{S}(9 \mathrm{C} / 69 \mathrm{C}$ ) for 5 days incubation, $500 \mathrm{nM}$ FRET labeled $\alpha \mathrm{S}(9 \mathrm{C} / 69 \mathrm{C})$ and $20 \mu \mathrm{M} \alpha \mathrm{S}$ for 3 days incubation, with and without $500 \mathrm{nM} \mathrm{N}$-protein. The prepared solutions were used to backfill the glass micropipettes. For injection the following settings were used: an injection pressure of $150 \mathrm{hPa}$, a constant pressure of $15 \mathrm{hPa}$, and a duration of the injection of 0.1 second. During injections the sample was observed on a Nikon TE2000 microscope (Nikon, Japan).

After microinjection, the cells were incubated for either 3 or 5 days. Subsequently the samples were washed with PBS (3x) and fixed in 3.7\% paraformaldehyde/PBS solution for 10 minutes at room temperature followed by an additional washing step with PBS. The cell nuclei were counterstained with 4',6-diamidino-2-phenylindole (DAPI) at a final concentration of $300 \mathrm{nM}$ for 10 minutes.

Analysis of cell images: To estimate the FRET efficiency we first applied a threshold to the recorded fluorescence intensity images. Only intensities exceeding the mean intensity $+3 x$ SD of each image were taken into account for the analysis of the FRET efficiencies. This thresholding was used to exclude background and noise from the analysis. From the thresholded FRET donor and acceptor fluorescence images, the $E_{F R E T}$ value per pixel was estimated as the ratio between intensity in the FRET acceptor channel divided by the sum of the intensities in the FRET donor and FRET acceptor channels. Note that these FRET efficiency values are estimates. We did not correct for acceptor cross excitation and donor bleed through in the acceptor channel since we only focus on differences within an image and changes between conditions. The mean FRET efficiency of all pixels in an image is represented as a single count in the cumulative histograms.

\section{Acknowledgements}

We would like to thank Kirsten A. van Leijenhorst-Groener for the production of the recombinant $\alpha$ synuclein protein. We are grateful to the Dutch Parkinson's disease foundation "Stichting ParkinsonFonds" for financial support.

\section{Author Contributions}

C.B., I.S.N. and M.M.A.E.C. designed research; M.A.A.F and S.A.S performed the research; S.A.S. and M.A.A.F. analyzed and interpreted the data; all authors contributed to writing the paper.

\section{Conflict of Interest}

The authors declare no conflict of interest. 
1. Song, E.; Zhang, C.; Israelow, B.; Lu-Culligan, A.; Prado, A. V.; Skriabine, S.; Lu, P.; Weizman, O.-E.; Liu, F.; Dai, Y.; Szigeti-Buck, K.; Yasumoto, Y.; Wang, G.; Castaldi, C.; Heltke, J.; Ng, E.; Wheeler, J.; Alfajaro, M. M.; Levavasseur, E.; Fontes, B.; Ravindra, N. G.; Van Dijk, D.; Mane, S.; Gunel, M.; Ring, A.; Kazmi, S. A. J.; Zhang, K.; Wilen, C. B.; Horvath, T. L.; Plu, I.; Haik, S.; Thomas, J.-L.; Louvi, A.; Farhadian, S. F.; Huttner, A.; Seilhean, D.; Renier, N.; Bilguvar, K.; Iwasaki, A., Neuroinvasion of SARS-CoV-2 in human and mouse brain. Journal of Experimental Medicine 2021, 218 (3).

2. Ramani, A.; Muller, L.; Ostermann, P. N.; Gabriel, E.; Abida-Islam, P.; Muller-Schiffmann, A.; Mariappan, A.; Goureau, O.; Gruell, H.; Walker, A.; Andree, M.; Hauka, S.; Houwaart, T.; Dilthey, A.; Wohlgemuth, K.; Omran, H.; Klein, F.; Wieczorek, D.; Adams, O.; Timm, J.; Korth, C.; Schaal, H.; Gopalakrishnan, J., SARS-CoV-2 targets neurons of 3D human brain organoids. Embo Journal 2020, 39 (20).

3. Paterson, R. W.; Brown, R. L.; Benjamin, L.; Nortley, R.; Wiethoff, S.; Bharucha, T.; Jayaseelan, D. L.; Kumar, G.; Raftopoulos, R. E.; Zambreanu, L.; Vivekanandam, V.; Khoo, A.; Geraldes, R.; Chinthapalli, K.; Boyd, E.; Tuzlali, H.; Price, G.; Christofi, G.; Morrow, J.; McNamara, P.; McLoughlin, B.; Lim, S. T.; Mehta, P. R.; Levee, V.; Keddie, S.; Yong, W.; Trip, S. A.; Foulkes, A. J. M.; Hotton, G.; Miller, T. D.; Everitt, A. D.; Carswell, C.; Davies, N. W. S.; Yoong, M.; Attwell, D.; Sreedharan, J.; Silber, E.; Schott, J. M.; Chandratheva, A.; Perry, R. J.; Simister, R.; Checkley, A.; Longley, N.; Farmer, S. F.; Carletti, F.; Houlihan, C.; Thom, M.; Lunn, M. P.; Spillane, J.; Howard, R.; Vincent, A.; Werring, D. J.; Hoskote, C.; Jager, H. R.; Manji, H.; Zandi, M. S.; N, U. C. L. Q. S. N. H. N., The emerging spectrum of COVID-19 neurology: clinical, radiological and laboratory findings. Brain 2020, 143, 3104-3120.

4. Mao, L.; Jin, H. J.; Wang, M. D.; Hu, Y.; Chen, S. C.; He, Q. W.; Chang, J.; Hong, C. D.; Zhou, Y. F.; Wang, D.; Miao, X. P.; Li, Y. N.; Hu, B., Neurologic Manifestations of Hospitalized Patients With Coronavirus Disease 2019 in Wuhan, China. JAMA Neurol. 2020, 77 (6), 683-690.

5. Taquet, M.; Geddes, J. R.; Husain, M.; Luciano, S.; Harrison, P. J., 6-month neurological and psychiatric outcomes in 236\&\#x2009;379 survivors of COVID-19: a retrospective cohort study using electronic health records. The Lancet Psychiatry.

6. Merello, M.; Bhatia, K. P.; Obeso, J. A., SARS-CoV-2 and the risk of Parkinson's disease: facts and fantasy. Lancet Neurol. 2021, 20 (2), 94-95.

7. Espay, A. J.; Henderson, K. K., Postencephalitic parkinsonism and basal ganglia necrosis due to Epstein-Barr virus infection. Neurology 2011, 76 (17), 1529-1530.

8. Bantle, C. M.; Phillips, A. T.; Smeyne, R. J.; Rocha, S. M.; Olson, K. E.; Tjalkens, R. B., Infection with mosquito-borne alphavirus induces selective loss of dopaminergic neurons, neuroinflammation and widespread protein aggregation. npj Parkinsons Dis. 2019, 5, 15.

9. Fishman, P. S.; Gass, J. S.; Swoveland, P. T.; Lavi, E.; Highkin, M. K.; Weiss, S. R., Infection of the basal ganglia by a murine coronavirus. Science 1985, 229 (4716), 877-879.

10. Vlajinac, H.; Dzoljic, E.; Maksimovic, J.; Marinkovic, J.; Sipetic, S.; Kostic, V., Infections as a risk factor for Parkinson's disease: a case-control study. Int. J. Neurosci. 2013, 123 (5), 329-332.

11. Maurizi, C. P., WHY WAS THE 1918 INFLUENZA PANDEMIC SO LETHAL - THE POSSIBLE ROLE OF A NEUROVIRULENT NEURAMINIDASE. Medical Hypotheses 1985, 16 (1), 1-5.

12. Ravenholt, R. T.; Foege, W. H., 1918 INFLUENZA, ENCEPHALITIS LETHARGICA, PARKINSONISM. Lancet 1982, 2 (8303), 860-864.

13. Harris, M. A.; Tsui, J. K.; Marion, S. A.; Shen, H.; Teschke, K., Association of Parkinson's disease with infections and occupational exposure to possible vectors. Mov. Disord. 2012, 27 (9), 1111-1117.

14. Limphaibool, N.; Iwanowski, P.; Holstad, M. J. V.; Kobylarek, D.; Kozubski, W., Infectious Etiologies of Parkinsonism: Pathomechanisms and Clinical Implications. Front. Neurol. 2019, 10, 11.

15. Aguzzi, A.; Rajendran, L., The Transcellular Spread of Cytosolic Amyloids, Prions, and Prionoids. Neuron 2009, 64 (6), 783-790. 
16. Brundin, P.; Melki, R.; Kopito, R., Prion-like transmission of protein aggregates in neurodegenerative diseases. Nature Reviews Molecular Cell Biology 2010, 11 (4), 301-307.

17. Prusiner, S. B., A Unifying Role for Prions in Neurodegenerative Diseases. Science 2012, 336 (6088), 1511-1513.

18. Ezzat, K.; Pernemalm, M.; Palsson, S.; Roberts, T. C.; Jarver, P.; Dondalska, A.; Bestas, B.; Sobkowiak, M. J.; Levanen, B.; Skold, M.; Thompson, E. A.; Saher, O.; Kari, O. K.; Lajunen, T.; Ekstrom, E. S.; Nilsson, C.; Ishchenko, Y.; Malm, T.; Wood, M. J. A.; Power, U. F.; Masich, S.; Linden, A.; Sandberg, J. K.; Lehtio, J.; Spetz, A. L.; El Andaloussi, S., The viral protein corona directs viral pathogenesis and amyloid aggregation. Nat. Commun. 2019, 10, 16.

19. Bar-On, Y. M.; Flamholz, A.; Phillips, R.; Milo, R., SARS-CoV-2 (COVID-19) by the numbers. elife 2020, 9, 15.

20. Yao, H. P.; Song, Y. T.; Chen, Y.; Wu, N. P.; Xu, J. L.; Sun, C. J.; Zhang, J. X.; Weng, T. H.; Zhang, Z. Y.; Wu, Z. G.; Cheng, L. F.; Shi, D. R.; Lu, X. Y.; Lei, J. L.; Crispin, M.; Shi, Y. G.; Li, L. J.; Li, S., Molecular Architecture of the SARS-CoV-2 Virus. Cell 2020, 183 (3), 730-+.

21. Verheije, M. H.; Hagemeijer, M. C.; Ulasli, M.; Reggiori, F.; Rottier, P. J. M.; Masters, P. S.; de Haan, C. A. M., The Coronavirus Nucleocapsid Protein Is Dynamically Associated with the ReplicationTranscription Complexes. J. Virol. 2010, 84 (21), 11575-11579.

22. Gallagher, T. M.; Buchmeier, M. J., Coronavirus spike proteins in viral entry and pathogenesis. Virology 2001, 279 (2), 371-374.

23. Yan, R. H.; Zhang, Y. Y.; Li, Y. N.; Xia, L.; Guo, Y. Y.; Zhou, Q., Structural basis for the recognition of SARS-CoV-2 by full-length human ACE2. Science 2020, 367 (6485), 1444-+.

24. Dutta, N. K.; Mazumdar, K.; Gordy, J. T., The Nucleocapsid Protein of SARS-CoV-2: a Target for Vaccine Development. J Virol. 2020, 16 (94), e00647-20.

25. Cubuk, J.; Alston, J. J.; Incicco, J. J.; Singh, S.; Stuchell-Brereton, M. D.; Ward, M. D.; Zimmerman, M. I.; Vithani, N.; Griffith, D.; Wagoner, J. A.; Bowman, G. R.; Hall, K. B.; Soranno, A.; Holehouse, A. S., The SARS-CoV-2 nucleocapsid protein is dynamic, disordered, and phase separates with RNA. bioRxiv 2020, 2020.06.17.158121.

26. Wolff, M.; Mittag, J. J.; Herling, T. W.; De Genst, E.; Dobson, C. M.; Knowles, T. P. J.; Braun, D.; Buell, A. K., Quantitative thermophoretic study of disease-related protein aggregates. Sci Rep 2016, $6,10$.

27. Chatterjee, S.; Molenaar, R.; Tromp, L.; Wagterveld, R. M.; Roesink, H. D. W.; Cornelissen, J.; Claessens, M.; Blum, C., Optimizing fluorophore density for single virus counting: a photophysical approach. Methods Appl. Fluoresc. 2021, 9 (2), 9.

28. Li, Y. W.; Zhao, C. Y.; Luo, F.; Liu, Z. Y.; Gui, X. R.; Luo, Z. P.; Zhang, X.; Li, D.; Liu, C.; Li, X. M., Amyloid fibril structure of alpha-synuclein determined by cryoelectron microscopy. Cell Res. 2018, 28 (9), 897-903.

29. Fakhree, M. A. A.; Engelbertink, S. A. J.; van Leijenhorst-Groener, K. A.; Blum, C.; Claessens, M., Cooperation of Helix Insertion and Lateral Pressure to Remodel Membranes. Biomacromolecules 2019, 20 (3), 1217-1223.

30. Fakhree, M. A. A.; Konings, I. B. M.; Kole, J.; Cambi, A.; Blum, C.; Claessens, M., The Localization of Alpha-synuclein in the Endocytic Pathway. Neuroscience 2021, 457, 186-195.

31. Fakhree, M. A. A.; Zijlstra, N.; Raiss, C. C.; Siero, C. J.; Grabmayr, H.; Bausch, A. R.; Blum, C.; Claessens, M., The number of alpha-synuclein proteins per vesicle gives insights into its physiological function. Sci Rep 2016, 6.

32. Burre, J.; Sharma, M.; Sudhof, T. C., alpha-Synuclein assembles into higher-order multimers upon membrane binding to promote SNARE complex formation. Proc. Natl. Acad. Sci. U. S. A. 2014, 111 (40), E4274-E4283.

33. Kaur, U.; Lee, J. C., Unroofing site-specific alpha-synuclein-lipid interactions at the plasma membrane. Proc. Natl. Acad. Sci. U. S. A. 2020, 117 (32), 18977-18983.

34. Lautenschlager, J.; Kaminski, C. F.; Schierle, G. S. K., alpha-Synuclein - Regulator of Exocytosis, Endocytosis, or Both? Trends Cell Biol. 2017, 27 (7), 468-479. 
35. Ramezani, M.; Wilkes, M. M.; Das, T.; Holowka, D.; Eliezer, D.; Baird, B., Regulation of exocytosis and mitochondrial relocalization by Alpha-synuclein in a mammalian cell model. $n p j$ Parkinsons Dis. 2019, 5.

36. Lautenschlager, J.; Stephens, A. D.; Fusco, G.; Strohl, F.; Curry, N.; Zacharopoulou, M.; Michel, C. H.; Laine, R.; Nespovitaya, N.; Fantham, M.; Pinotsi, D.; Zago, W.; Fraser, P.; Tandon, A.; St George-Hyslop, P.; Rees, E.; Phillips, J. J.; De Simone, A.; Kaminski, C. F.; Schierle, G. S. K., C-terminal calcium binding of alpha-synuclein modulates synaptic vesicle interaction. Nat. Commun. 2018, 9, 13.

37. Ferreon, A. C. M.; Gambin, Y.; Lemke, E. A.; Deniz, A. A., Interplay of alpha-synuclein binding and conformational switching probed by single-molecule fluorescence. Proc. Natl. Acad. Sci. U. S. A. 2009, 106 (14), 5645-5650.

38. Veldhuis, G.; Segers-Nolten, I.; Ferlemann, E.; Subramaniam, V., Single-Molecule FRET Reveals Structural Heterogeneity of SDS-Bound alpha-Synuclein. ChemBioChem 2009, 10 (3), 436-+.

39. Fakhree, M. A. A.; Nolten, I. S.; Blum, C.; Claessens, M., Different Conformational Subensembles of the Intrinsically Disordered Protein alpha-Synuclein in Cells. J. Phys. Chem. Lett. 2018, 9 (6), 1249-1253.

40. Vaneyck, J.; Segers-Nolten, I.; Broersen, K.; Claessens, M. M. A. E., Cross-seeding of alphasynuclein aggregation by amyloid fibrils of food proteins. Journal of Biological Chemistry 2021, 296.

41. Shvadchak, V. V.; Claessens, M.; Subramaniam, V., Fibril Breaking Accelerates alpha-Synuclein Fibrillization. J. Phys. Chem. B 2015, 119 (5), 1912-1918.

42. Shvadchak, V. V.; Falomir-Lockhart, L. J.; Yushchenko, D. A.; Jovin, T. M., Specificity and Kinetics of alpha-Synuclein Binding to Model Membranes Determined with Fluorescent Excited State Intramolecular Proton Transfer (ESIPT) Probe. Journal of Biological Chemistry 2011, 286 (15), 13023 13032.

43. Binolfi, A.; Rasia, R. M.; Bertoncini, C. W.; Ceolin, M.; Zweckstetter, M.; Griesinger, C.; Jovin, T. M.; Fernandez, C. O., Interaction of alpha-synuclein with divalent metal ions reveals key differences: A link between structure, binding specificity and fibrillation enhancement. J. Am. Chem. Soc. 2006, 128 (30), 9893-9901.

44. Semerdzhiev, S. A.; Dekker, D. R.; Subramaniam, V.; Claessens, M., Self-Assembly of Protein Fibrils into Suprafibrillar Aggregates: Bridging the Nano- and Mesoscale. ACS Nano 2014, 8 (6), 55435551.

45. Usov, I.; Mezzenga, R., FiberApp: An Open-Source Software for Tracking and Analyzing Polymers, Filaments, Biomacromolecules, and Fibrous Objects. Macromolecules 2015, 48 (5), 12691280. 